\title{
Estado nacional e migração Bolívia - Brasil: categorização e recategorização da popula- ção migrante
}

\section{Heloisa Mazzoccante ${ }^{1}$}

\section{Resumo:}

Buscamos questionar o papel dos Estados sobre o processo de (re)categorização da população migrante, considerando que o imigrante em situação de irregularidade perante o Estado - a exemplo da comunidade boliviana em São Paulo -, que já sofre certa categorização no país de origem, estaria sendo recategorizado no trânsito migratório.

Palavras-chave: migração, trabalho escravo, políticas migratórias, direitos humanos, cidadania, integração.

\section{Introdução}

A partir dos anos 1970, diante das crescentes dificuldades dos Estados em lidar com o fenômeno de uma progressiva imigração e com a fixação dos imigrados em seu território, aumentam as medidas restritivas e seletivas ao ingresso de imigrantes e os processos de exclusão discriminatória. Uma parcela dos imigrantes os "sem qualificações profissionais" e em "situação sócio-econômica desprivilegiada" - é mantida em condições precárias de subsistência, mediante falta de documentação, desvantagens econômicas e negação de direitos. Em meio a esse contexto, avolumam os questionamentos acerca da idéia de nação e sobre a relação entre imigração e Estado nacional e, de igual maneira, acerca das políticas e mecanismos de integração dos imigrantes nas novas sociedades. A crescente diversidade cultural bem como a estratificação interna de direitos são elementos que contribuem para significativas mudanças em certas instituições políticas, a exemplo da cidadania, o que implica a própria natureza do Estado nacional1.

No Brasil, a política de imigração e colonização baseou-se em um conjunto de ações pelas quais se buscou atrair imigrantes, o que foi responsável pelo incremento e direcionamento da imigração no início do século XIX até parte do século XX. No entanto, ao lado dos mecanismos de atração, permaneceram, em variados períodos, práticas de restrição à entrada de pessoas no território nacional. Com a radicalização da política imigratória ao longo dos anos, as ações estatais se direcionaram para as tentativas de obstruir a imigração coletiva de estrangeiros que não se "identificam com a cultura latina" como propagado pelo discurso dominante no séc. XX - a exemplo de judeus e japoneses, ou com os parâmetros estabelecidos pela legislação estatal. As políticas de atração foram cedendo lugar para as de controle, respaldadas por leis mais autoritárias e restritivas. Atualmente, uma série de resoluções do Conselho Nacional de Imigração regulamenta e, por vezes, facilita e incentiva a vinda de pessoas para o Brasil, obedecendo aos critérios de preenchimento de mão-de-obra especializada nos vários setores da

1 Possui graduação em Bacharelado em Ciências Sociais pela Universidade Federal de Goiás (1985). Atualmente é assessora técnica - Secretaria de Indústria e Comércio e professora auxiliar da Universidade Católica de Goiás.Doutorado em andamento em Estudos Comparados sobre as Américas 
economia nacional (cientistas, técnicos de alto nível, investidores e outros). Os critérios de seleção tornaram-se normas regulamentares aplicadas a todas as pessoas oriundas de outras localidades.

Na pauta das discussões sobre as políticas migratórias, enquanto persistirem os muros e as fronteiras - objetivas e simbólicas - reitera-se a premência de que sejam ampliados os mecanismos estatais para a inclusão jurídica dos imigrantes. As transformações demandadas pelo atual contexto de internacionalização da economia requerem mudanças na dimensão política, em detrimento da crença de que "a economia mundial fará o serviço da política" (Leis, 2002).

$\mathrm{Na}$ esfera do Cone Sul, a retórica em torno da imigração, especialmente a de caráter limítrofe, vem sofrendo uma nova abordagem por parte de alguns governos, a exemplo da Argentina, Brasil e Bolívia. Enquanto a política dominante dos anos 1980/90 esteve impregnada pela noção de migração intrarregional ou limítrofe como ameaça, quer na esfera da segurança, quer na defesa do trabalhador nacional, o atual discurso oficial tem versado em favor da abertura das fronteiras, com maior inclusão dos imigrantes, à luz dos direitos humanos e de uma perspectiva integrativa.

As atuais pesquisas demonstram o panorama de crescimento no estabelecimento de imigrantes regionais no território brasileiro, em especial de bolivianos, cujo estatuto social tende a ser o novo elemento de distinção entre as categorias de desejáveis e indesejáveis 2 e, portanto, sujeitos/não-sujeitos às políticas governamentais. Chama especial atenção o elevado número de imigrantes em situação legal irregular, os chamados "indocumentados" ou "ilegais", sendo a maior parte proveniente da Bolívia.

A polarização em torno do mercado de trabalho e do aumento das taxas de desemprego, de um lado, e do caráter político, que gravita na defesa da autonomia dos Estados nacionais, na uniformidade cultural, na identidade nacional e na coesão social, de outro, coloca em lados opostos os nacionais e os imigrantes. A categorização de cidadania assentada nas bases do tradicional sistema de Estado-nação tende a condenar à qualidade de habitantes de "segunda classe" aqueles que não são considerados membros, pelas leis dos Estados, nos novos locais de estabelecimento. Os processos de seleção à entrada e permanência de pessoas em dado território não são característicos apenas dos atuais fluxos do processo de globalização, mas inerentes à própria história da imigração e dos imigrantes (Radhay, 2006).

Os reflexos das fronteiras internas e externas se manifestam, entre outras coisas, no privilegiamento de determinadas categorias de imigrantes ou de certas nacionalidades. A esses é concedida uma espécie de cidadania tutelada ou regulada, cujo conceito é definido por Santos (1979, p. 74) como um tipo de cidadania que não se baseia em um código de valores políticos, mas em um sistema de estratificação ocupacional, e que é definido por norma legal. Seguindo essa mesma lógica, o sujeito dos direitos passa por uma decisão do Estado, que, na maioria das vezes, obedece a critérios centrados nos interesses econômicos nacionais. Como bem definido por Ianni (1996), com a globalização do capitalismo e a nova divisão transnacional do trabalho, o próprio exercício da cidadania sofre um condicionamento em relação às forças que atuam em escala global. Nessa perspectiva, a construção da cidadania implica, como um todo, práticas conflituosas vinculadas ao poder na definição dos sujeitos e dos problemas comuns que deverão ser incluídos nas políticas dos Estados.

Por outro lado, a parcela de indivíduos que não é aceita pelas normas vigentes no país receptor - a categoria de indesejados - tende a viver à margem dos direitos. Em tal contexto, parte dos imigrados transita para a condição denominada subclasse, composta pelos extensos bolsões de exclusão, por minorias e grupos ét- 
nicos, onde estão também incluídos os refugiados, que, como definido por Bauman (2005, p. 46), são "desterritorializados num mundo de soberania territorialmente assentada". Em tais circunstâncias, a relação entre migração, ausência de direitos e exploração tende a ser facilmente instituída.

Como afirma Ramos (2003), consideramos que as políticas públicas não são embasadas em estruturas preexistentes, mas, ao contrário, representam um lócus de construção dessas estruturas. Nesse sentido, as ações demandadas em nome do Estado são consideradas elementos que atuam na produção da autoridade estatal, logo, na própria construção do Estado. Em semelhante perspectiva, as políticas públicas - ou a ausência delas - dirigidas à população migrante exercem um papel revelador quanto à maneira de como o Estado elabora a sua definição de imigrante, tendo em vista a construção/manutenção da ordem por ele instituída e a legitimação da sua autoridade. Por outro lado, o imigrante em situação de irregularidade perante as normais estatais, que pela proveniente condição socioeconômica já seria objeto de dada categorização no país de origem, estaria sofrendo uma recategorização no trânsito migratório, fruto das políticas no país receptor.

\section{Panorama migratório: América Latina- Brasil/Bolívia}

A despeito da atual tendência, com acentuados movimentos de pessoas dos países em desenvolvimento para os desenvolvidos, verifica-se o crescimento do deslocamento intrarregional em toda a América Latina e Caribe. Ao compor o próprio contexto historicamente compartilhado entre países com relações sociais, políticas, econômicas e culturais, o fluxo humano fronteiriço na região remonta a antigas datas. Segundo a CEPAL (2006), a maioria da população migrante atualmente presente na região é oriunda da própria América Latina
(58,7\%). A Argentina e a Venezuela têm sido os principais pólos receptores ou de destino, e a Colômbia o principal país de origem dos imigrantes intrarregionais (Villa; Martínez Pizarro, 2001). Já o Brasil é o quinto maior emissor intrarregional, com estimativas que apontam para mais de 200 mil pessoas morando em países vizinhos, especialmente Paraguai (150 mil), Bolívia (25 mil), Argentina (30 mil) e Uruguai (10 mil). Os outros quatro maiores emissores de imigrantes intrarregionais são Colômbia, Paraguai, Chile e Bolívia (Baeringer, 2002).

Herdeiro de um passado colonial de origem europeia, o Brasil recebeu grande quantidade de pessoas entre o século XIX e parte do século XX, quando foram adotadas políticas de estímulo à imigração em massa. Após a Segunda Guerra Mundial, a América Latina recebe a última grande leva de imigrantes europeus, tendo como principais destinos a Argentina, o Brasil e a Venezuela (Lattes, A; Latttes, Z., 1996). Apesar de o Brasil ser o terceiro maior receptor de imigrantes no Cone Sul, o número de estrangeiros regulares vem se mantendo estável há pelo menos dez anos, girando em torno de um milhão de pessoas. Em dezembro de 2006, contabilizou-se um total de 817.855 registros de imigrantes permanentes no país (SINCRE, 2006). No entanto, as estimativas indicam que o número de imigrantes "indocumentados" esteja próximo ou até supere a quantidade de regulares (980 mil em 1996, segundo recadastramento efetuado pela Polícia Federal). Com 170 milhões de habitantes, o contingente de imigrantes regularizados no país mantém-se em torno de 0,6 por cento da população.

Os registros no Serviço de Estatísticas de Estrangeiros da Polícia Federal demonstram o crescimento da comunidade boliviana na cidade de São Paulo: 255 pessoas em 1995, passando para 17.897 em 1999. Pelo censo demográfico de 1991, a comunidade boliviana no Brasil era de 15.694 pessoas, enquanto em 2000 os registros eram de 20.388 imigrantes, o que representa 
um aumento de $23 \%$ no período (Baeringer; Souchaud, 2007). Pelas estimativas do Ministério Público Federal, em 2005 havia em torno de 200 mil bolivianos na capital paulista, entre regulares e irregulares3 (CPI do Trabalho Escravo, 2005). É preciso considerar que em decorrência da situação de invisibilidade da comunidade boliviana, as pesquisas censitárias não abrangem significativa parcela dos imigrados, podendo-se crer, ademais, que o sub-registro dos bolivianos tende a ser maior do que o de outras comunidades instaladas no país. A mais provável explicação para tal fato é que, dada a fragilidade da comunidade boliviana no país - em razão do seu estatuto social, falta de documentação e vulnerabilidade, estes não são beneficiários diretos de políticas migratórias ao se instalarem4. Dessa maneira, torna-se possível um intrínseco paralelo entre o sub-registro de uma população estrangeira com a situação de fragilidade no local de estabelecimento. (Baeringer e Souchaud, 2007).

Do total de imigrantes sem documentação, boa parte vive e trabalha em condições consideradas precárias e degradantes em mais de 8 mil oficinas de costuras ilegais. O Sindicato das Costureiras em São Paulo estima que haja cerca de 80 mil trabalhadores irregulares, incluindo os bolivianos submetidos às condições descritas, ou seja, em regime de escravidão nas oficinas de costura (CPI - Trabalho Escravo, 2005).

A Bolívia, além de atualmente ser considerada região de trânsito, possui uma trajetória migratória que a converteu, ao longo dos anos, em país expulsor de pessoas. A baixa expectativa de desenvolvimento decorrente da estrutura social e econômica, aliada à instabilidade política e à miséria de determinadas regiões, caracterizam o país como pólo de emigração de mão-de-obra. Pelas estimativas, mais de dois milhões de bolivianos emigraram entre os anos 2001 e 2005, o que representa um quantitativo superior a $16 \%$ da população do país (8.274.325 habitantes em 2001). Em 2007 contabilizou-se um total de três milhões de bolivianos vivendo em países como Estados Unidos, Comunidade Européia, Canadá, Austrália, Argentina, Brasil e Ásia (Plaza, 2007: 26). No Cone Sul, Brasil e Argentina são os principais receptores dos emigrantes mais pobres, fato que mantém relação com o baixo custo de transportes, comparativamente aos países centrais, além das facilidades para atravessar a extensa fronteira que os separa da Bolívia.

\section{Quadro I}

\begin{tabular}{|c|c|c|}
\hline & Brasil & São Paulo \\
\hline $\begin{array}{l}\text { População total } \\
\text { de imigrantes } \\
(2007)\end{array}$ & $\begin{array}{l}183,9 \\
\text { milhões }\end{array}$ & 19 milhões \\
\hline $\begin{array}{l}\text { População imi- } \\
\text { grante com regis- } \\
\text { tro }\end{array}$ & $\begin{array}{l}817.855 \mathrm{mil} \\
(2006)\end{array}$ & $\begin{array}{l}195.641 \mathrm{mil} \\
(2000)\end{array}$ \\
\hline $\begin{array}{l}\text { População imi- } \\
\text { grante sem regis- } \\
\text { tro }\end{array}$ & $\begin{array}{l}800 \text { a } 900 \mathrm{mi} \\
(2006)\end{array}$ & Sem registro \\
\hline $\begin{array}{l}\text { Imigrantes boli- } \\
\text { vianos com regis- } \\
\text { tro }\end{array}$ & $\begin{array}{l}20.388 \mathrm{mil} \\
(2000)\end{array}$ & $\begin{array}{l}200 \mathrm{mil} \\
(2005)\end{array}$ \\
\hline $\begin{array}{l}\text { Imigrantes boli- } \\
\text { vianos sem regis- } \\
\text { tro }\end{array}$ & $\begin{array}{l}\text { Acima de } \\
200 \mathrm{mil} \\
(2005)\end{array}$ & $\begin{array}{l}100 \text { e } 150 \\
\text { mil (2005) }\end{array}$ \\
\hline $\begin{array}{l}\text { Trabalhadores } \\
\text { bolivianos na in- } \\
\text { dústria de con- } \\
\text { fecções }\end{array}$ & Sem registro & $80 \mathrm{mil}$ \\
\hline
\end{tabular}

* Dados compilados pela autora através da utilização de diversas fontes: Câmara de Comércio Argentino Brasileira de São Paulo, Polícia Federal, Ministério Público Federal, Sindicato das Costureiras de São Paulo, Consulado Boliviano na Argentina, CEPAL, Comissão Mundial sobre Migrações Internacionais, IBGE.

**Considerando a inexistência de fontes seguras quando se trata de imigração sem registro, há variação de dados segundo a fonte, além de que os dados utilizados são números aproximados

No Brasil, a imigração boliviana tem início na década de 50, quando os dois países esta- 
beleceram um programa de intercâmbio cultural que atraiu estudantes em busca de qualificação acadêmica não disponível na Bolívia. Muitos desses estudantes acabaram por permanecer na cidade de São Paulo (Silva, 2006: 159). A partir da década de 1970 começam a chegar pessoas com baixa qualificação para trabalhar nas oficinas de costura a pequenos salários, o que em muito contribuiu para mudar o perfil do imigrante boliviano na cidade.

Os governos da região têm avançado em ampla quantidade de Tratados e Convênios visando facilitar o trânsito de pessoas, as migrações em função de trabalho, a segurança social, o trânsito vicinal fronteiriço, controles únicos de fronteiras e a regularização de imigrantes que ainda se encontram sem permissão legal para permanecer no país. Os Convênios propõem compromissos bilaterais sobre políticas e programas migratórios de desenvolvimento e de direitos, geração de emprego e projetos comuns que visam a melhoria das condições de vida dos imigrantes. No entanto, há um descompasso na relação entre o acordado e a sua aplicação. Como a regulamentação é limitada pelas normas internas dos países, que por sua vez sofrem outros condicionamentos (pressões políticas, opinião pública e pressões econômicas) provenientes do que vem se tornando uma espécie de "negócio migratório" -, os acordos tendem a permanecer sem a devida efetividade (Mármora, 2002).

Sob a coordenação do Ministério da Justiça do Governo Brasileiro, encontra-se em fase de elaboração, desde 2004, o anteprojeto da nova Lei de Migração e Naturalização, em substituição à legislação de 1980. A nova lei, além de buscar resguardar os direitos civis e fundamentais do imigrante, previstos na Constituição de 1988, teria como objetivo assegurar tratamento diferenciado aos imigrantes sul-americanos, visando maior integração econômica, política, social e cultural dos povos da região. Nessa perspectiva, a política imigratória brasileira esta- ria voltada à garantia dos direitos humanos ao imigrante, deixando de ser tratada como uma questão de segurança nacional, como orientado pela legislação ainda em vigor, elaborada pelo governo militar durante o regime de exceção.

A situação migratória na Bolívia é regida, desde 1996, apenas por um Decreto Supremo (DS 24423). A ausência de legislação que direcione a política imigratória no país faz com que os órgãos que tratam da questão, como o Servicio Nacional de Migración (SENAMIG) e a Chancelaria boliviana, tenham ações aleatórias e, por vezes, contraditórias, embasados por uma situação conjuntural. O ingresso e a saída de pessoas no país, bolivianos ou estrangeiros, nem sempre passa por controles fronteiriços com os países limítrofes: Brasil, Argentina, Peru e Chile. Desde o início de vigência do Decreto Supremo e salvo a elaboração de um projeto de lei que ainda deve encontrar-se no Senado, o país não obteve nenhum avanço em relação à questão migratória. Segundo informes do Governo Constitucional da Bolívia (2007), uma equipe do governo vinha discutindo junto a setores da sociedade civil sobre a elaboração de uma nova política migratória, com participação social, e na qual o eixo articulador estivesse voltado para os direitos humanos.

\section{Imigrante boliviano: as indústrias de confecção em São Paulo e trabalho es- cravo}

Ao longo do século XX e até a década de 1970, a comunidade judia lidera a atividade na indústria do vestuário de São Paulo, porém, já em torno de 1960 tem início a contratação de mão-de-obra coreana. O significativo aumento no contingente de pessoas a ingressarem no país até o final dos anos 70 contribui enormemente para que esta comunidade prosperasse, passando a liderar a atividade nas oficinas de costura através do emprego da mão-de-obra dos próprios coreanos (Keum, 1991). Ao findar o fluxo de 
migração coreana, os empregadores do setor contratam, inicialmente, mão-de-obra proveniente da região nordeste do Brasil, que não se adaptou ao ritmo e às condições de trabalho impostas nas confecções. Protegidos pela legislação trabalhista brasileira, os trabalhadores nordestinos freqüentemente recorriam à Justiça do Trabalho em prol dos seus direitos5.

A liberalização econômica e comercial na Argentina, Brasil e Bolívia, a partir dos anos de 1980 , acentua a concentração da renda, o aumento da pobreza e do desemprego, bem como o empobrecimento dos estratos sociais médios, acelerando os fluxos de emigração para os países mais ricos, ao mesmo tempo em que favorece a situação de informalidade. Em vista das dificuldades no emprego da força de trabalho dos brasileiros, principalmente de origem nordestina, a opção dos empregadores nas oficinas de costura da cidade de São Paulo recai sobre os trabalhadores imigrantes, particularmente os bolivianos, acentuando sua entrada no país nesse período (Cacciamali e Azevedo, 2006).

O fluxo emigratório na região assume nova proporção a partir de meados da década de 1990, com as sucessivas crises econômicas e sociais na Argentina intensificando a entrada de pessoas no Brasil (Patarra, 1995). Tal fato é favorecido, ademais, pela vigência do novo plano econômico brasileiro, em 1994, o que irá interferir novamente na rota de imigrantes bolivianos em direção à Argentina. A procedência de regiões (andinas) extremamente pobres, a submissão, a disposição para longas jornadas de trabalho e a habilidade na costura e na tecelagem tornam essa mão-de-obra bastante atraente nas oficinas de costura na cidade de São Paulo6. Com tradição no associativismo, seja na esfera religiosa, cultural ou de trabalho, o emigrante andino "é conduzido de seu local de origem para um enclave étnico, onde é encerrado entre seus pares" (Cacciamali e Azevedo, 2006).

Alguns estudos têm sido dedicados ao tema da exploração e das precárias condições a que são submetidos os trabalhadores (imigrantes) nas oficinas de costura em São Paulo, particularmente os de origem boliviana, dada sua grande quantidade numérica (Silva, 1997; CPI do trabalho escravo, 2005; Cacciamali e Azevedo, 2006; dentre outros). A exploração no trabalho é facilitada pela dificuldade com o idioma nacional, a necessidade de subsistência e a vulnerabilidade gerada em decorrência da condição de ilegalidade no país. Tal realidade retrata grande paradoxo em pleno processo de integração da região do Cone Sul: para os tecnocratas, primeiro se deve priorizar a circulação de bens e dos fatores de produção, reservando para segundo plano as decisões quanto à movimentação humana e de trabalhadores. Como evidenciam Pitanguy e Heringer (2001:5), os indivíduos e organizações envolvidos com a defesa dos direitos humanos têm sido frequentemente excluídos do diálogo, quando se negligencia o nexo crítico entre comércio e direitos.

Ao longo do processo histórico, os migrantes têm exercido importante parcela de contribuição na produção de bens materiais e imateriais, na prestação de serviços de baixa remuneração e essenciais. Ao mesmo tempo em que as atuais condições da economia mundial contribuem para que um número cada vez maior de pessoas deixe seus locais de nascimento em busca de níveis de vida mais satisfatórios, as empresas tendem a implementar políticas que minimizem cada vez mais seus custos, intensificando o recurso de mão-de-obra flexível e barata, categoria na qual os imigrantes estão inseridos, principalmente aqueles que se encontram em condições irregulares7. Necessários à produção e reprodução do capital, os imigrantes ditos "indocumentados" contribuem para reduzir ainda mais os custos de produção, gerando mercadorias de alta competitividade.

A migração continua, de todo modo, se processando sob amplas condições de precariedade, gerando conseqüências como a vulnerabi- 
lidade, a exploração e as atuais modalidades de trabalho escravo.

A escravidão atual se caracteriza por uma série de novos fatores, como a carência de informações dos direitos, falsas promessas feitas pelo aliciador como: bons salários; boa estrutura de trabalho e alojamento; ausência de emprego e condições de manutenção própria e da família na região de origem. Os escravocratas contemporâneos são em sua maioria produtores que possuem modernos e avançados recursos de produção, são proprietários de latifúndios e conquistaram suas riquezas principalmente nos últimos trinta anos (Nunes, 2005).

Paralelamente ao combate do trabalho escravo rural, que tem sido alvo de reiterada atenção do governo brasileiro, o registro de diversos casos de utilização dessa mão-de-obra no setor de confecções enuncia certo descaso com a situação de permanência de semelhantes condições de vida e trabalho no meio urbano. Os imigrantes de origem boliviana - mas também são crescentes os casos de paraguaios e chilenos - embarcam sem recursos suficientes para custear a viagem, em resposta aos anúncios dos rádios e jornais nos países de origem, que solicitam "costureiros para trabalhar no Brasil. Se paga trezentos dólares por mês com direito à moradia e à alimentação" 8 . A oferta engloba um adiantamento a ser pago com trabalho nas oficinas de costura no país vizinho, entretanto, diante da supervalorização dos custos da viagem e a pequena quantia recebida pelo trabalho realizado, os bolivianos podem exercer as suas atividades durante vários meses, sem remuneração, para quitar a dívida inicial (CPI Trabalho Escravo, 2005).

A falta de uma definição clara na legislação brasileira do que vem a ser "condição análoga à de escravo" suscita dúvidas na aplicação da lei penal, assim como dificulta o enfrentamento do problema. A imprecisão de conceitos conduz a que se recorra aos instrumentos internacionais que dispõem acerca do tema, os quais passaram a integrar o ordenamento jurídico brasileiro quando da sua ratificação pelas autorida- des competentes, tornando o País deles signatário.

Tanto a imprensa quanto os órgãos governamentais, as entidades religiosas, as ONGs e outros vêm utilizando diversos termos para caracterizar a exploração do trabalho no Brasil, dentre eles a expressão trabalho escravo, acompanhada por adjetivos como novo, atual, moderno, contemporâneo. Seja qual for a adjetivação empregada, a violência gerada pelo trabalho escravo aos direitos humanos na contemporaneidade pode ser equiparada à cometida em suas formas mais tradicionais, indicando que mecanismos de exploração do sobre-trabalho humano presentes na América do período colonial reaparecem na fase de maior desenvolvimento tecnológico e científico do capitalismo.

$\mathrm{Na}$ condição de trabalhadores em regime de escravidão, tanto em sua forma atual quanto no modelo antigo, os trabalhadores são submetidos a subterfúgios que visam preservar a submissão: ameaças, violências psicológicas, coerções e punições. Segundo Sento-Sé (2000), o trabalho escravo, na atualidade, pode ser descrito como aquele em que

o empregador sujeita o empregado a condições de trabalho degradantes, inclusive quanto ao meio ambiente em que irá realizar a sua atividade laboral, submetendo-o, em geral, a constrangimento físico e moral, que vai desde a deformação do seu consentimento ao celebrar o vínculo empregatício, passando pela proibição imposta ao obreiro de resilir o vínculo quando bem entender, tudo motivado pelo interesse mesquinho de ampliar os lucros às custas da exploração do explorador.

Alguns atos ensejam a prática de trabalho escravo, podendo ser identificados na contemporaneidade. Estes são apontados por Lima Santos (2003):

a. a constrição da vontade inicial do trabalhador em se oferecer à prestação de serviços, sendo, por isso, constrangido à prestação de trabalhos forçados sem sequer emitir sentimento volitivo neste sentido (geralmente esta situação ocorre com os filhos dos trabalhadores sujeitos a trabalho escravo e seus familiares); 
b. o aliciamento de trabalhadores em uma dada região com promessas de bom trabalho e salário em outras regiões, com a superveniente contratação de dívidas de transportes, de equipamento de trabalho, de moradia e alimentação, cujo pagamento se torna obrigatório e permanente, determinando a chamada escravidão por dívida; c. o trabalho efetuado sob ameaça de uma penalidade - como ameaças de morte com armas -, geralmente violadora da integridade física ou psicológica do empregado; modalidade que quase sempre segue a escravidão por dívidas; d. a coação, pelos proprietários de oficinas de costura dos grandes centros urbanos - como São Paulo - de trabalhadores latinos pobres e sem perspectivas em seus países de origem geralmente bolivianos e paraguaios -, que ingressam irregularmente no Brasil. Os empregadores apropriam-se de sua documentação e os ameaçam de expulsão do país, por meio de denúncias às autoridades competentes. Obstados de locomoverem-se para outras localidades, diante da sua situação irregular, os trabalhadores submetem-se às mais vis condições de trabalho e de moradia (coletiva).

Quanto ao Código Penal Brasileiro (artigo 149), condição análoga à de escravo corresponde às situações em que o sujeito é submetido a "trabalhos forçados ou a jornada exaustiva, quer sujeitando-o a condições degradantes de trabalho, quer restringindo, por qualquer meio, sua locomoção em razão de dívida contraída com o empregador ou preposto". Entretanto, diversos questionamentos têm sido suscitados em relação à descrição desse dispositivo, uma vez que o mesmo não esclarece claramente o que pode ser considerado condição análoga a de escravo, gerando dúvidas quanto à aplicação da lei penal.

Entende-se por trabalho escravo a instituição social que consiste, em síntese, no direito de propriedade sobre seres humanos com a utilização de seus serviços. Para o Procurador do Ministério Público do Trabalho no Estado do Maranhão, Maurício Pessoa Lima (2002), a expressão trabalho em condições análogas à de escravo seria o mecanismo encontrado para "desvencilhar a figura jurídica do escravo en- quanto sujeito de propriedade, das modernas formas de escravidão"10. Nessa perspectiva, torna-se necessário estabelecer as devidas diferenciações entre o trabalho em condições análogas à de escravo e o trabalho degradante, ou a super exploração do trabalhador.

[...] o labor degradante é aquele no qual o trabalhador é submetido a condições intoleráveis que atentem contra a sua rigidez física e mental, agravadas pelo fato de não serem observadas as normas de higiene e segurança, nem serem dadas condições para uma alimentação razoável. [...]

Já na super-exploração ocorre a supressão dos direitos trabalhistas mais básicos. Como exemplo, temos o não pagamento sequer do salário-mínimo, a exigência de jornadas excessivas ou altas cotas de produção, geralmente acompanhadas de fraudes.

Segundo Lima, para que se configure a situação análoga à de escravo é preciso que além da ocorrência de condições precárias de trabalho se constate o cerceamento da liberdade de locomoção do trabalhador, seja por meio de fraude ou de violência.

Com efeito, o trabalho em condições análogas à de escravo é espécie do gênero "trabalho forçado", cujo conceito é mais amplo, pois envolve desde situações decorrentes do trabalho de prisioneiros de guerra, até a utilização do trabalho como forma de castigo (pena), conforme observamos na Convenção no 29 da OIT.

Assim, restará configurado o trabalho em condições análogas à de escravo toda vez que encontrarmos o cerceamento da liberdade de ir e vir por meio de qualquer das seguintes formas, que podem se apresentar combinadas ou isoladamente, quais sejam: fraude; dívida; retenção de salários; retenção de documentos; isolamento em regiões remotas ou de difícil acesso e violência.

Em regra o cerceamento da liberdade do trabalhador se faz acompanhar de maustratos, ou ainda da submissão a trabalho degradante. 


\section{Práticas migratórias: categorização e recategorização dos imigrantes}

As dificuldades impostas à migração num momento histórico em que são propiciados os intercâmbios de bens e idéias em tempo real revelam as assimetrias de uma globalização que inclui indivíduos, populações, países e regiões, mas que é ao mesmo tempo excludente (Casttels, 1999). Para além do quadro individualista, representado pela decisão racional do sujeito - que o leva a migrar, o desequilíbrio estrutural freqüente é motivo de atração dos migrantes para os mercados de trabalho das regiões de destino (Piore, 2002), quando os desequilíbrios mundiais de poder e riqueza definem os 'caminhos' coletivos para a imigração. A clivagem social coloca em posições antagônicas os que estão dentro e os que são privados de participar dos diversos níveis de poder, com a negação de direitos fundamentais.

As migrações envolvem uma multiplicidade de fenômenos: social, demográfico, cultural, político, psicológico, não havendo uma teoria geral específica que englobe todos eles em um só arcabouço teórico. Nesse sentido, Jansen referere-se à migração como

um problema demográfico: influencia a dimensão das populações na origem e no destino; é um problema econômico: muitas mudanças na população são devidas a desequilíbrios econômicos entre diferentes áreas; pode ser um problema político: tal é particularmente verdade nas migrações internacionais, onde restrições e condicionantes são aplicadas àqueles que pretendem atravessar uma fronteira política; envolve a psicologia social, no sentido em que o migrante está envolvido num processo de tomada de decisão antes da partida, e porque a sua personalidade pode desempenhar um papel importante no sucesso com que se integra na sociedade de acolhimento; e é também um problema sociológico, uma vez que a estrutura social e o sistema cultural, tanto dos lugares de origem como de destino, são afetados pela migração e, em contrapartida, afetam o migrante (Jansen 1969 apud Peixoto, 2004:4).

Ao lado da questão das migrações internacionais, a crescente diversidade étnica e cultural nas sociedades tem merecido especial atenção nos países ocidentais. Se as fronteiras nacionais e territoriais foram severamente controladas e guardadas pelos Estados em diversos momentos históricos (e ainda o são), os imperativos sistêmicos e os atuais efeitos da dinâmica econômica global imprimem um novo caráter à mobilidade espacial de pessoas. As transformações verificadas de forma generalizada ao redor do mundo, de caráter não só econômico, mas social, político, cultural e ideológico, têm provocado o isolamento de indivíduos e a fragmentação de comunidades em muitas partes do globo - quebra da integração dos espaços sociais e culturais -, processo que está se tornando cada vez mais evidente. (Lindgren Alves, 2001).

O contexto vivido pelos imigrados face às dificuldades enfrentadas como minoria étnica, os enfrentamentos de ordem econômica, cultural, de ameaça ao mercado de trabalho no país receptor, desencadeiam uma tensão que acaba por se alojar na rejeição da diferença. Ocorre, dessa maneira, um deslocamento dos problemas centrados na precariedade econômica rumo às questões étnicas, com um processo de etnização das diferenças sociais. Os traços biológicos são ressaltados ("biologizados") em um conjunto de indivíduos considerados de uma mesma categoria social. Sem "direito a ter direitos", ao serem excluídos socialmente os imigrados se marginalizam culturalmente formando os guetos e as comunidades étnicas.

Quanto aos deslocamentos intra-regionais, ainda que se considere a existência de traços tradicionais entre os países do Cone Sul, com proximidades não só geográficas, mas também em seus processos sociais, os mesmos são considerados movimentos migratórios interna- 
cionais. Dada a presença de fronteiras políticas entre os países, a imigração intra-regional pode ser configurada como uma "modalidade de migração interna dos respectivos países, uma vez que os deslocamentos significam uma extensão transfronteiriça dos mesmos processos sociais" (Palau, 1997 apud Patarra, 2002:36).

No Cone Sul vem se acentuando indícios de uma reconfiguração dos discursos e políticas do Estado quanto ao tratamento das migrações internacionais, centrando-se na diversidade cultural e na retórica da inclusão, com vistas à cidadania e direitos humanos11. Diferentemente das décadas passadas, o discurso oficial do Estado tem se voltado menos para a imigração limítrofe como ameaça ou problema (como adotado pela doutrina da segurança nacional), mas procurando destacar, ao contrário, os benefícios da imigração, com uma clara tentativa de promover e intensificar a imagem de tolerância, de inclusão, de abertura à diversidade e à pluralidade. A retórica da abertura e da integração está aliada à inserção dos imigrantes na sociedade de destino, o que deve contemplar, obviamente, questões relativas à incorporação social, econômica (principalmente laboral), política e cultural dos mesmos.

Entretanto, como adverte Domenech, a utilização da categoria integração para referir-se ao processo de incorporação dos imigrantes na sociedade de acolhimento não conduz necessariamente ao abandono da idéia de assimilação, demonstrando ser, em geral, mais uma alternativa a esta e uma contraposição à noção de segregação. A categoria integração pode ser remetida ao sentido de "acomodação" na perspectiva do consenso ou equilíbrio social. Segundo a autora, "acorde a la visión funcionalista, la "integración" es conceptualizada como uma necessidad y un fin u objetivo que procura el consenso y define el orden social" (Domenech, 2007:31). Pela definição impressa na obra "Diplomacia parlamentar - uma contribuição ao debate", publicado pelo Instituto Universitas
(2008), integração refere-se ao "estabelecimento de normas harmônicas de interesses, de cooperação, de atividades entre pessoas ou entre regiões ou Estados". Nessa ótica, pode-se supor que a proposta em torno da idéia de integração não assegura transcender a perspectiva liberal sobre a diversidade cultural, levando-se em consideração que se aloja na idéia de igualdade formal e na visão de reciprocidade, consenso e harmonia entre os distintos grupos sociais e étnicos.

Para Grimson (2006), no momento em que a hipersensibilização das diferenças tornase marca predominante nas sociedades ocidentais, as esferas governamentais e os organismos internacionais, ao promovem o discurso da diversidade, se distanciam da noção de multiculturalismo crítico, aproximando-se basicamente do que seria um multiculturalismo pluralista. Nesse sentido, a construção da diferença pode representar um novo modelo de exclusão quando da materialização de práticas associadas ao pluralismo cultural. Vale recordar as afirmações de Garcia, Granados e Pulido (1996:2): "la construcción de la diferencia no es más que una nueva forma de presentar las distancias culturales, sociales y políticas que son legitimadas bajo la experiencia de ausencia de jerarquías sociales pero que ocultam un refinado mecanismo de exclusión".

Segundo Domenech (2007:34), "la diferencia pode estar asociada tanto a nociones de "enriquecimento cultural" como a la ideia de "desventaja" ou "deficiencia". Tal mecanismo de diferenciação não está ligado exclusivamente a contextos migratórios ou multiculturais, porém, nesse caso particular adquire um caráter específico ao etnificar a diferença cultural ou social. Para Balman (2001:83), "a etnicidade se cria para parecer que se baseia em diferenças absolutas e naturais, em lugar de basear-se em eleições relativas e culturais de diferenciação ou de diferenças criadas".

As características - reais ou atribuídas - 
que fazem com que o imigrante se diferencie das demais pessoas podem consolidar-se em uma identidade étnica ou nacional "alheia". O peso material e simbólico de cada coletividade e as representações que recaem sobre a aparência fenotípica, além da língua, dos costumes, da religião, dentre outras características, bem como a posição ocupada na estrutura social e sua identidade de classe são fatores determinantes para que o outro diferente seja ou não aceito em maior ou menor escala (Domenech, 2007). Ainda que existam práticas e discursos que denotem um esforço no sentido do reconhecimento da diferença, são predominantes os posicionamentos que demonstram a abertura à diversidade afinada com a visão pluralista liberal, que não relaciona o reconhecimento cultural com a redistribuição social, gerando, numa sociedade não igualitária, a idéia de equivalência cultural. A hierarquização social promove, de igual maneira, diferentes graus de poder e variadas possibilidades de ação, distribuídos pelos diversos setores da sociedade.

Não é demais lembrar que os imigrantes, ao se situarem em regiões inferiores na hierarquia de poder, acabam por experimentar variadas formas de estigmatização e etnização: em primeiro lugar, a representação do outro, no sentido daquele que é estrangeiro, estranho, o que dificulta sua aceitação na sociedade. Em seguida, a ausência de conexão com a ordem jurídica interna dos Estados conduz a que estes passem a viver à margem da lei - na qualidade de "indocumentados" - quando lhes é negado o direito à permanência em dado território. Como complementam Garcia, Granados e Pulido (1996: 23):

La categoría de extranjero, que aparentemente sólo tiene la carga lingüística de ser extraño, tiene además la carga cultural de ser diferente, de ser «otro» y, sobre todo, tiene la carga jurídica de no ser ciudadano. De manera burda se puede afirmar que un extranjero es aquél que «no es natural» de um país distinto del suyo lo que supone, desde el punto de vista de la plena protección y de amparo constitucional, no ser ciudadano, con lo que ello conlleva de ausencia de derechos.

Ademais, como minorias étnicas, sem papéis e em decorrência do próprio estatuto social, os imigrantes acabam por se tornarem sujeitos das categorizações, sendo freqüentemente convertidos em criminosos, delinqüentes, inimigos. Bauman (2005) sintetiza minorias étnicas como populações que se situam às margens do sistema de dominação, nos "não-lugares", permanecendo condenados a estereótipos, cuja imagem é imposta por outros. Nos novos contextos de ação, ou seja, no país de recepção, as relações interativas e as instituições tecem a maneira como os imigrantes se definem, ou como estes se resignificam, tendo por base a representação e/ou a sua identificação de origem.

A reflexão a respeito das forças que interagem sobre a categorização/recategorização da população migrante abrange as diversas dimensões do poder e suas teias, visíveis e invisíveis. Seguindo a acepção de poder simbólico, elaborada por Bourdieu, este se define por "uma relação determinada - e por meio desta - entre os que exercem o poder e os que lhe estão sujeitos [...]" (2007: 14-15). Trata-se de um “(...) poder invisível que só pode se exercer com a cumplicidade daqueles que não querem saber que a ele se submetem ou mesmo que o exercem". O exercício de tal poder pressupõe o reconhecimento, sendo, para tanto, ignorado como arbitrário. Podemos acrescentar, entretanto, que o reconhecimento, a cumplicidade e a legitimação do poder não se configuram como fatores impeditivos à ação - a exemplo dos imigrantes "indocumentados" -, cuja motivação pode estar acima de qualquer ordem estabelecida. Se o exercício do poder impresso nas palavras e palavras de ordem tem como uma das potencialidades a manutenção da própria ordem, como descrito por Bourdieu, pode-se supor que o imigrante que deixa seu país de origem e se submete à condição de "indocumentado", "irregular" ou 
"ilegal" no país receptor não necessariamente deixa de reconhecer o poder, pois, se de um lado ele não se submete de imediato à autoridade estabelecida, já que juridicamente encontra-se irregular, de outro, ao se inserir e permanecer no país sem documentação, portanto vulnerável e sem direitos, esse imigrante estaria, de alguma maneira, legitimando a ordem vigente.

A discussão sobre os fluxos migratórios recentes pode, por outro lado, ser inserida no interior de uma problemática mais ampla vinculada aos desdobramentos contemporâneos do capitalismo, e do qual o Estado atua, de modo peremptório, como centro de poder. Nos tempos atuais, longe de representar um processo basicamente opcional, a imigração está circunscrita à esfera de uma necessidade estrutural da acumulação capitalista em um estado avançado. Nesse sentido, pode ser pertinente pensar as especificidades dos novos movimentos migratórios vinculados a circuitos econômicos informais de produção e comercialização, como nos Estados Unidos e Europa, como também para os circuitos Sul-Sul (Portes, 1999).

Dessa maneira, como aponta Portes, possivelmente não terão eficácia as estratégias de recrudescimento das leis de imigração com vistas a transformar as estruturas envolvidas em tais fluxos, já que não se trata de mera questão opcional dos indivíduos, mas, antes, de mecanismos estruturais das economias capitalistas em suas configurações mais desenvolvidas. De outra forma, o Estado, ao inserir um novo discurso de promoção dos direitos humanos e de maior integração dos imigrantes à sociedade - a exemplo do que vem ocorrendo em alguns países da América do Sul - sem deixar de promover a economia capitalista, cria uma aura humanista, o que irá contribuir ainda mais fortemente para a eficácia do poder simbólico.

Regulamentar o trânsito fronteiriço da população tornou-se função imediata dos Estados modernos, com as leis de nacionalidade cumprindo o papel de controle restritivo desse movimento. A idéia de nação vinculada à de Estado torna a identidade nacional a mais articulada das identidades territoriais, levando a que a representação de espaço, que caminha proximamente ao nascimento do Estado moderno, se constitua logo em instrumento de poder e do "Poder". Com a moderna organização política da sociedade e a intrínseca fusão ideológica entre nacionalidade, cidadania e identidade nacional (Stolcke, 2001), o próprio conceito de cidadania ficou impresso em uma fundamentação territorial, critério pelo qual se distingue os cidadãos dos não-cidadãos, ainda que estes partilhem com os primeiros do mesmo espaço geopolítico.

Ao adotar a concepção de soberania, coube às políticas estatais a definição das novas cidadanias e, por pressuposto, dos novos sujeitos de direitos. O privilegiamento de determinadas categorias de imigrantes encontra respaldo nas diretrizes políticas voltadas para o desenvolvimento/progresso, quando a essência dos critérios seletivos tem por embasamento o conhecimento especializado e a primazia do fator econômico.

A acepção político-ideológica que correlaciona a noção de cidadão com a de nação, definindo a dimensão do primeiro pelo pertencimento a um "espaço eminentemente público", estabelece o conjunto de direitos e deveres para com a nação, entidade também universal. Os direitos inerentes ao "cidadão-indivíduo" fora da delimitação territorial do Estado nacional a que pertence revela um dos grandes paradoxos da política contemporânea: a discrepância entre os esforços idealistas na consideração dos direitos desfrutados pelos cidadãos como inalienáveis e a situação de seres humanos sem direitos.

O uso do conceito de cidadania, em sua conotação universalizante, tornou-se um elemento de distinção e de exclusão na medida em que as "escolhas" e "preferências" na esfera social revelam uma prática desigual e hierarquizada, já que ao lado de noções como "ideologia 
do mérito", por exemplo, ela acaba por permitir discriminar e recriar privilégios. Diante dos mecanismos de discriminação social e política, desmistifica-se a crença da igualdade enquanto idéia fundamental no conceito de cidadania, já que, em contextos históricos e sociais diferentes são engendrados diferentes tratamentos e práticas sociais, mesmo considerando a semelhante noção de cidadania e o mesmo conceito de indivíduo (Da Matta,1987).

A análise do Estado transita, necessariamente, pela abordagem de entidade não autônoma, mas definido enquanto um "conjunto de práticas sociais, instituições e poderes que, a partir das dinâmicas intra e inter-Estados que ordenam as cadeias de interdependência que ligam indivíduos e grupos, são centralizados e territorializados em processos de longa duração" (Elias, 1993). De maneira semelhante, a produção do território é induzida por uma articulação de ações ou de comportamentos e conduz a "sistemas de malhas, de nós e de redes" (observáveis ou não, pois podem fazer parte da esfera das decisões). A diferenciação implícita na ordenação do território, se por um lado é funcional, por outro obedece a um princípio hierárquico da importância atribuída pelos sujeitos, individuais ou em grupos, às suas diversas ações (Raffestin, 1993).

A idéia de território pressupõe, além do espaço físico - que é apropriado e do qual o primeiro é formado -, um processo maior de construção de signos, de representações. Para Lefebvre (1978), um território nacional é um espaço físico "balizado, modificado, transformado pelas redes, circuitos e fluxos que aí se instalam [...]". A delimitação de territórios, de fronteiras, entre outras coisas, implica em que os Estados sempre modularam suas políticas espaciais concomitantemente com as relações de poder.

Bourdieu (2007) igualmente reflete acerca da idéia de região, argumentado que esta não deve ser reportada a uma realidade natural, mas implica uma rede de relações a partir da qual se estabelecem outras relações, tanto de proximidade como de distância. O grau, o volume, as características, a complexidade que podem assumir essas relações vão depender de diversas variáveis, dentre as quais a atuação dos canais de comunicação. $\mathrm{Na}$ atualidade, com o crescente desenvolvimento dos canais de comunicação, as idéias de centro e de fronteiras perdem cada vez mais o seu sentido, o que inclusive leva a pensar a região sob novos parâmetros: ela deixa de parecer um espaço isolado entre fronteiras e dependente de um centro, com tendências a se tornar um complexo de relações inserido numa rede sem fronteiras.

Diante da crescente integração tempo/espaço, cresce o debate - nos fóruns reunindo acadêmicos e entidades envolvidas com a problemática migratória - acerca da concepção de cidadania universal, em defesa da diminuição e quebra das barreiras impostas pelos Estados nacionais à mobilidade humana. Nesse sentido, lembramos o pensamento Hardt e Negri, para quem

O virtual e o possível se conjugam [na mobilidade]. A virtualidade do espaço mundo constitui primeira determinação do movimento da multidão - uma virtualidade que pode vir a ser real. Espaço que pode vir a ser tranversalizado, pode vir a ser espaço de vida: circulação pode vir a ser liberdade. Em outras palavras, a multidão móvel deve adquirir uma cidadania global... Nomadismo e miscigenação podem vir a ser figuras de virtude, como práticas éticas no terreno do Império. Desde tal perspectiva o espaço objetivo da globalização capitalista se quebra. A celebração do local, nestes tempos, pode ser repressiva se se opõe à circulação, à mistura e assim reforçar os muros da nação, da etnicidade, da raça, do povo. Mas o local pode ser enriquecido, se não definido por isolamento e pureza...fronteiras são questionadas..... poder de circulação é uma determinação primeira da virtualidade da multidão, e o direito à circulação um primeiro ato ético para uma ontologia contra imperial. (Hardt e Negri, 2000: 363)

Apesar da persistência das barreiras ao ingresso de pessoas, nos maiores países receptores, o crescente fluxo migratório destaca certa 
incompatibilidade entre as posturas restritivas e um mundo que avança no sentido da crescente liberação de outros fluxos. O aumento de tais situações torna patente a necessidade da implementação de acordos mais amplos entre os países, de maneira a reduzir o incremento dos casos de falta de documentação, facilitar o acesso aos direitos humanos fundamentais e a valorização da pessoa humana. Como nos lembra Trouillot (2001), se há uma crescente rotineirização da presença estatal nas vidas dos cidadãos em todas as localidades, tornando seu poder mais visível e invasor, por vezes este poder tem também se mostrado menos efetivo e relevante. Afinal, ressalta o autor, as análises sugerem que a globalização verte o Estado não somente como ator econômico, mas também como recipiente social e cultural.

Aqui é interessante interrogar o paralelo colocado por Sayad (1991) acerca da relação entre país de emigração e de imigração, ao destacar o segundo como pólo dominante e plenamente soberano na definição das políticas dirigidas aos imigrantes. Nessa visão, as ações estatais ficariam reservadas à esfera exclusiva dos países receptores, as quais transitam entre uma regulação mínima - ou mesmo à sua ausência quanto aos deslocamentos dos imigrantes e o estabelecimento de critérios de seleção, restrição e assimilação destes. Caberia, portanto, aos agentes estatais do país de imigração o papel ativo na questão imigratória?

\section{Referências bibliográficas:}

ANTUNES, Ricardo. Adeus ao trabalho? Ensaio sobre as Metamorfoses e a Centralidade do Mundo do Trabalho. São Paulo: Cortez; Campinas, SP: Editora da Universidade Estadual de Campinas, 2006.

BHABHA, Homi K. O local da cultura. Belo Horizonte: Editora UFMG, 2005.
BAENINGER, Rosana. La migración internacional de los brasileños: características y tendencias, Santiago de Chile: CELADE/CEPAL, 2002.

BAENINGER, Rosana e SOUCHAUD, Sylvain. Vínculos entre a Migração Internacional e a Migração Interna: o caso dos bolivianos no Brasil. Oficina Nacional sobre "Migración interna y desarrollo en Brasil: diagnóstico, perspectivas y políticas"

Organizado por Comisión Económica para América Latina y el Caribe, CELADE-División de Población. 30 de Abril 2007, Brasilia, Brasil.

BARRETO, Luiz Paulo Teles Ferreira. Consideração sobre a imigração no Brasil contemporâneo. In: CNPD. Migrações internacionais: Contribuições para políticas, 2003.

BARTH, Fredrik. Grupos étnicos e suas fronteiras. In: POUTIGNAT, Philippe e STREIFFFENART, Jocelyne. Teorias da etnicidade: seguido de grupos étnicos e suas fronteiras de Fredrik Barth. São Paulo: Editora Fundação da Unesp, 1998.

BAUMAN, Zigmund. Identidade. Rio de Janeiro: Jorge Zahar Ed., 2005.

Rio de Janeiro: Jorge Zahar, 2001.

Modernidade Líquida.

BOAVENTURA, Souza Santos. Por uma Concepção Multicultural de Direitos Humanos. Revista Crítica de Ciências Sociais - No 48. Junho de 1997.

BOURDIEU, Pierre. O poder simbólico. Tradução Fernando Tomaz. $11^{a}$ edição. Rio de Janeiro: Bertrand Brasil, 2007.

BRASIL. Ministério Público da União. Procura- 
doria Geral do Trabalho. Revista do Ministério público do Trabalho. Ed. Especial. Trabalho escravo. Ano XIII, no 26, Brasília: LTr, 2003.

CACCIAMALI, Maria Cristina \& CHAHAD, José Paulo Zeetano. Dilemas da erradicação do trabalho forçado no Brasil. In: Mercado de Trabalho no Brasil: novas práticas trabalhistas, negociações coletivas e direitos fundamentais no trabalho. São Paulo: Editora LTr., 2003.

CACCIAMALI, Maria Cristina e AZEVEDO, Flávio Antonio Gomes. Entre o Tráfico Humano e a Opção da Mobilidade Social: os Imigrantes Bolivianos na Cidade de São Paulo. Cadernos PROLAM/USP (ano 5 - vol. 1 2006), p. 129-143.

CARDOSO DE OLIVEIRA, Roberto. Identidade, etnia e estrutura social. São Paulo: Livraria Pioneira, 1976.

CASTELLS, Manuel. A sociedade em rede. São Paulo: Paz e Terra, 1999.

CASTLES, Stephen \& MILLER, Mark, J. The age of Migration - International population Movements in the Modern World. Cf. PEIXOTO, João Alfredo. Migrações internacionais e globalização: Mobilidade, mercado de trabalho e relações sociais. In: SCHERER-WARREN, Ilse e FERREIRA, José Maria C. (Orgs.) Transformações sociais e dilemas da globalização: Um diálogo Brasil-Portugal, 2002.

CASTRO, Mary Garcia. Algumas provocações sobre cultura política e cidadania. Palestra proferida no Fórum Social Mundial, Porto Alegre RS, 2002.

"Comentários sobre

Textos del Tema Gobernabilidad de la Migracion Intenacional y Diplomacia Multilateral". In: Simposio sobre Migración Internacional en las
Américas, CEPAL/CELADE/OIM, San José, 2000.

CELADE - Centro Latinoamericano y Caribeño de Demografia, OIM - Organizacion Internacional para lãs Migraciones, UNFPA - Fondo de Población de lãs Naciones Unidas, 2003.

Centro de Investigación y Estudios Avanzados de la Población UAEM. Papeles de POBLACIÓN. Nueva Época. Año 8. Nº. 33. Julio-septiembre de 2002.

CEPAL - Comissão Econômica para América Latina e Caribe. Migración internacional, derechos humanos y desarrollo, 2006.

CERQUEIRA, Carlos Magno Nazareth: A Polícia e os Direitos Humanos: Estratégias de Ação. IPRI - Instituto de Pesquisas de Relações Internacionais. Seminário Direitos Humanos no Século XXI, Rio de Janeiro, 1998.

COMISSÃO MUNDIAL SOBRE AS MIGRAÇÕES INTERNACIONAIS. As migrações num mundo interligado: Novas linhas de acção. Tradução Elsa Oliveira, Lda/Carlos Fiúza. Fundação Calouste Gulbenkian. Ministério do Emprego e Trabalho. Assessoria Internacional. Relatório de Atividades. Outubro, 2005.

DA MATTA, Roberto. A casa \& a rua. Rio de Janeiro: Editora Rocco, 1987.

DOMENECH, Eduardo E. Migraciones contemporáneas y pluralismo cultural em la Argentina: El discurso oficial y las prácticas escolares. In: Cartogradias da imigração: Interculturalidade e Políticas Públicas. JARDIM, Denise Fagundes (org.); colaboração de VILLALÓN, Adriana Maria [et al.]. Porto Alegre: Editora da UFRGS, 2007.

ELIAS, Norbert. O processo civilizador, v. 2: 
formação do Estado e civilização. Rio de Janeiro: Zahar Editores, 1993.

GIDDENS, A. As consequências da modernidade. São Paulo: Editora da Universidade Estadual Paulista, 1991.

GOTTMANN, Jean. The significance of territory. Charlottesville: The University Press of Virginia, 1973

GRIMSON, Alejandro. Nuevas xenofobias étnicas em la Argentina. In: GRIMSON, Alejandro \& JELIN, Elizabeth (comp.). Migraciones regionales hacia la Argentina: Diferencia, desigualdad y derechos. Buenos Aires: Prometeo, 2006.

HALL Stuart. A Identidade Cultural na Pósmodernidade. DP\&A Editora, 2005.

Da diáspora. Belo Horizonte: Editora UFMG, 2003.

HARDT, Michael e NEGRI, Antônio. "Empire"- Havard University Press, Cambridge, 2000, apud CASTRO, Mary Garcia "Comentários sobre Textos del Tema Gobernabilidad de la Migracion Intenacional y Diplomacia Multilateral". In: "Simposio sobre Migración Internacional en las Américas", CEPAL/CELADE/OIM, San José, 2000.

HARVEY, D. The condition of Post-Modernity. Oxford: Oxford University Press, 1989.

IANNI, Otávio. A racialização do mundo. In: Tempo Social, Revista de Sociologia da USP, 8 (1), 1996 a, pp. 1-23.

JANSEN, Clifford J. (1969), "Some sociological aspects of migration", in J.A. Jackson (Ed.), Migration, Cambridge, Cambridge University Press, pp. 60-73.
KEUM, Joa Choi. "Além do arco-íris: a imigração coreana no Brasil". Dissertação (Mestrado em História Social) - Faculdade de Filosofia, Letras e Ciências Humanas da Universidade de São Paulo, 1991.

LACLAU, E. New Reflexions on the Resolutin of our Time. Londres: Verso, 1990.

LATTES, A \& LATTES, Z. R. International migration in Latin America. Apud LINDGREN ALVES, José Augusto. Relações Internacionais e temas globais: A década das conferências. Brasília: IBRI, 2001.

LEIS, Héctor Ricardo. Cidadania e globalização: novos desafios para antigos problemas. In: Ilse Scheres-Warren, José Maria Carvalho Ferreira (orgs.) Transformações sociais e dilemas da globalização: um diálogo Brasil / Portugal, 2002.

LEFEBVRE, Henri. De l'État 4. Les contraditiones de l'État moderne. Paris: UGE, 1978.

LESSER, Jeffrey. Welcoming the Undesirables Brazil and the Jewish Question. University of California Press, 1995 - E.I.A.L. Estudios Interdisciplinarios de America Latina y el Caribe Volumen 6 - no 2 julio - diciembre 1995.

LIMA SANTOS, Ronaldo de. BRASIL. Ministério Público da União. Procuradoria Geral do Trabalho. Revista do Ministério público do Trabalho. Ed. Especial. Trabalho escravo. Ano XIII, $\mathrm{n}^{\mathrm{o}} 26,2003$, p. 55-56.

MÁRMORA, Lélio. Migrações e Política na América Latina: Novos espaços e Cenários. In: SALES, Teresa e SALLES, Maria do Rosário (Orgs.). Políticas Migratórias: América Latina, Brasil e brasileiros no exterior. São carlos: EdUFSCAR: Editora Sumaré, 2002.

MARCUS, George. Past, present and emergent 
identities: requirements for ethnografhies of late Twenth Century Modernity worldwide (Mimeo) Apud RIBEIRO, Gustavo Lins. Bichos-deObra: fragmentação e reconstrução de identidades. Revista Brasileira de Ciências Sociais $n^{\circ} 18$, ano 7, fev. 1992.

MAZZOCCANTE R., Heloisa. "Política imigratória no Brasil contemporâneo: limites e desafios na relação entre direitos humanos, democracia e desenvolvimento.” Dissertação (Mestrado) - Centro de Estudos Comparados das Américas (CEPPAC), Universidade de Brasília, Brasília, 2007.

MELO, Graça e FRANCO, Giuliana (orgs.). Diplomacia parlamentar - uma contribuição ao debate. Instituto Universitas. Brasília - DF: DGrau Multimídia Ltda, 2008.

MENEZES, Lená Medeiros. Movimentos e políticas em perspectiva histórica: Um balanço do século XX. In: CNPD. Migrações internacionais: Contribuições para políticas, 2001.

NUNES, Flávio Filgueiras. "A persistência do trabalho escravo no Brasil". Monografia de conclusão de curso apresentada à Faculdade de Ciências Jurídicas e Sociais Vianna Júnior, na cidade de Juiz de Fora - MG, em maio de 2005.

PALAU, T. Migracion among countries in Mercosul: trends and perspectives, 1997. Barcelona: IUSSP, n 7-10, mai. 1997. Apud PATARRA, Neide. Migrações internacionais e integração econômica no Cone Sul: Notas para discussão. In: Políticas Migratórias: América Latina, Brasil e brasileiros no exterior, 2002.

PATARRA, Neide Lopes. Migrações Internacionais e Integração Econômica no Cone Sul: Notas para discussão. In: SALES, Tereza e SALLES, Maria do Rosário (Orgs.). Políticas Migratórias: América Latina, Brasil e brasileiros no exterior. São Carlos: EdUFSCar: Editora Sumaré, 2002.

PEIXOTO, João Alfredo. Migrações internacionais e globalização: Mobilidade, mercado de trabalho e relações sociais. In: SCHERER-WARREN, Ilse e FERREIRA, José Maria C. (Orgs.) Transformações sociais e dilemas da globalização: Um diálogo Brasil-Portugal, 2002.

"As teorias Explica-

tivas das Migrações: teorias Micro e Macro-Sociológicas", 2004. Texto originalmente publicado em As Migrações dos Quadros Altamente Qualificados em Portugal - Fluxos Migratórios Inter-Regionais e Internacionais e Mobilidade Intra-Organizacional. Dissertação de doutoramento, Lisboa, Instituto Superior de Economia e Gestão, Universidade Técnica de Lisboa, 1998.

PITANGUY, Jacqueline \& HERINGER, Rosana (Orgs). Direitos Humanos no Mercosul. Cadernos Fórum Civil Ano 3 N. 4. Rio de Janeiro, janeiro 2001.

PLAZA, Jorge Mondaca. Migración laboral y flujos migratorios. In: Miradas sobre la Migracion Boliviana. Capítulo Boliviano de Derechos Humanos, Democracia y Desarrollo. La Paz, Bolívia, 2007.

PORTES, A., "Modes of structural incorporation and present theories of labor immigration", in KRITZ, M. et al. (eds.), Global trends in migration, New York, Center for Migration Studies, 1981.

. La mondialisation par le bas -

l'émergence des communautés transnationales. In: Actes de la Recherche en Science Sociales, $\mathrm{n}^{\circ}$ 129, setembro de 1999: 15 - 25. 
REIS, Rossana Rocha. Soberania, direitos humanos e migrações internacionais. Revista Brasileira de Ciências Sociais, Vol. 19, N 55, Junho/2004.

RADHAY, Rachel Annelise. "Discurso e Poder na Política de Imigração Brasileira”. Tese (Doutorado). Instituto de Letras - Departamento de Lingüística, Línguas Clássicas e Vernáculas. Universidade de Brasília, Brasília, 2007.

RAFFESTIN, Claude. Por uma geografia do poder. São Paulo: Ed. Ática, 1993.

RIBEIRO, Gustavo Lins. Bichos de Obra: fragmentação e reconstrução de identidades. Revista Brasileira de Ciências Sociais no 18 , ano 7 , fev. 1992.

SAID, Edward. Orientalism. Londres: Penguin, 1994.

SANTOS, Wanderley Guilherme dos. Cidadania e justiça: a política social na ordem brasileira. Rio de Janeiro: Campus, 1994.

SENTO-SÉ, J. L. de A. Trabalho escravo no Brasil na atualidade, 2000.

SILVA, Sidney A. da. Costurando sonhos: Trajetória de um grupo de bolivianos em São Paulo. São Paulo: Paulinas, 1997.

Hispano-americanos no Brasil: Entre a cidadania sonhada e a concedida. In: Migrações Internacionais - Contribuições para políticas. Brasília: CNPD, 2001.

SINCRE - Sistema Nacional de Cadastramento e Registro de Estrangeiros, 2006.

SOARES, Luiz Eduardo: Novas políticas de segurança pública. Revista de Estudos Avançados, vol.17, n. 47, 2003.
SPRANDEL, Márcia. "Migrações internacionais e a sociedade civil brasileira". In: em CNPD: Migrações Internacionais/ Contribuições para Políticas, Brasília: Governo Federal, 2001.

. "O parlamento e as migrações internacionais”. In: Migrações Internacionais: Contribuição para políticas. Brasília: CNPD, 2001.

STOLCKE, Verena. A "natureza" da nacionalidade. In: Raça como retórica: a construção da diferença. Claidia Barcellos Rezende e Yvonne Maggie (organizadoras). Rio de Janeiro: Civilização Brasileira, 2001.

TOUILLOT, Michel-Rolph. The Antropology of the State in the Age of Globalization. Chicago: Departament of Antropology. University of Chicago, 2001.

VILLA, Miguel, e MARTÍNEZ PIZARRO, Jorge, "Tendencias y patrones de la migración internacional em América Latina y el Caribe". In: CEPAL: La migración internacional y el desarrollo en las Américas, Nações Unidas, Santiago de Chile, 2001.

\section{Endereços eletrônicos}

Acordo Brasil/Bolívia de Regularização Migratória de 13 de setembro de 2005. Disponível em $<$ http://www.dpf.gov.br/web/servicos/acordo _brasil_bolivia.htm> Acesso em 07 de dezembro de 2006.

Agência Senado. Legislação Federal e outros. Disponível em $<$ http://www.senado.gov.br/sf>. Acesso em 05 de março de 2007.

América latina: a escravidão boliviana nas indústrias têxteis do Brasil e da Argentina. Disponível em <http://www.movimentonn.org/noticia $>$ 
Acesso em 26 de agosto de 2007.

Bolivianos migram com sonho de trabalhar. Associação Brasileira de Jornalismo Independente - ABRAJI. Disponível em $<$ http://www.abraji.org.br> Acesso em 18 de agosto de 2006.

CDH - Comissão de Direitos Humanos. Relatório das Atividades de 1998. Disponível em $<$ http://www.dhnet.org.br> Acesso em 07/10/2006.

CAMI - Centro de Apoio ao Migrante. Disponível em <http://www.migracoes.com.br/centro $>$. Acesso em 06 de setembro de 2006.

CPI para Apurar a Exploração de Trabalho Análogo ao de Escravo nas Empresas, Regular ou Irregularmente Instaladas em São Paulo, Relatório Final, 2005. Disponível em <http://www.camara.sp.gov.br/cpi_TrabalhoEscravo/001.htm >. Acesso em 01 de junho de 2006.

CDHM - Direitos Humanos e Minorias. Disponível em <http://www.camara.gov.br> . Acesso em 03 de janeiro de 2007.

GARCIA CASTANO, Javier; GRANADOS MARTÍNEZ, Antolín \& PULIDO MOYANO, Rafael. Reflexiones em diversos âmbitos de construción de la diferencia. Disponível em http:/ / www.juntadeandalucia.es/gobernacion/opencms/portal/Politicas Migratorias/Publicaciones/materiales_forinter/modulo2/garci a_2>. Acesso em 05 de junho de 2008.

LEVÍN, Silvia. "La ciudadanía social argentina en los umbrales del siglo XXI". Revista KAIROS N 4, 2008. Disponível em: $<$ http://www.revistakairos.org/k04-05.htm>. Acesso em 08 de setembro de 2008.

MARINUCCI, Roberto e MILESI, Rosita. As migrações internacionais contemporâneas, 2006. Disponível em: < www.migrante.org.br > Acesso em 10 de outubro de 2006.

OIT BRASIL: http://www.oitbrasil.org.br/trabalho_forcado/brasil/documentos/texto.

Projetos de Lei e Outras Proposições. Disponível em <http://www.camara.gov.br>. Acesso em 02 de novembro de 2006.

Situação de imigrantes bolivianos em São Paulo e queixas quanto ao consulado. Bolivianos declaram guerra a cônsul. Publicado em 11/02/04. Disponível em <http://noticias.uol.com.br/>. Acesso em 12 de janeiro de 2007. 